\title{
SUBDOMÍNIOS HIDROGEOLÓGICOS DO AQUÍFERO POROSO DE PORTO VELHO, RONDÔNIA, BRASIL
}

\author{
HYDROGEOLOGIC SUBDOMAINS OF A POROUS AQUIFER FROM PORTO VELHO, \\ RONDÔNIA, BRAZIL
}

\author{
Maíra Hilgemberg ALVES, Vanderlei MANIESI \\ Email: mairageologia@gmail.com, vanderleimaniesi@gmail.com

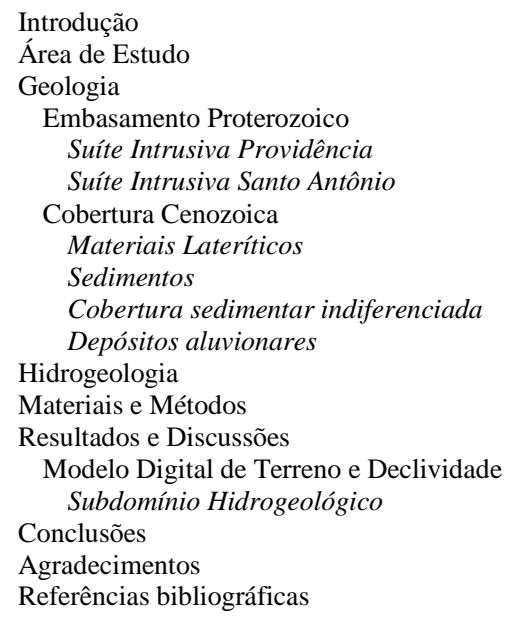

Univiversidade Federal de Rondônia - UNIR. Av. Pres. Dutra, 2967 - Olaria, Porto Velho - RO

RESUMO - Estudos hidrogeológicos foram desenvolvidos na zona urbana da cidade de Porto Velho, Rondônia, que compreende um sistema hidrogeológico poroso, heterogêneo e anisotrópico, possuindo propriedades de aquíferos livres, bem como semiconfinados quando envoltos por aquitardo. Constitui-se por coberturas cenozoicas com espessura média de 61,8 metros que sobrepõe às rochas granitoides do embasamento regional. A estratigrafia de 189 poços tubulares de captação de água subterrânea possibilitou a identificação do domínio hidrogeológico poroso e seus subdomínios laterítico e sedimentar. O subdomínio laterítico (materiais do perfil laterítico) possui produtividade baixa a muito baixa e vazão específica média de $0,26 \mathrm{~m}^{3} / \mathrm{h} / \mathrm{m}$. No subdomínio sedimentar (depósitos sedimentares), foram identificadas as zonas hidrogeológicas aluvionar, aquitardo e sedimentos indiferenciados. A zona aluvionar denota produtividade alta a muito alta (vazão específica média de $11,4 \mathrm{~m}^{3} / \mathrm{h} / \mathrm{m}$ ) e localiza-se na porção leste da área de estudo. Por outro lado, a zona aquitardo apresenta produtividade muito baixa (vazão específica média de $0,39 \mathrm{~m} 3 / \mathrm{h} / \mathrm{m}$ ) e localiza-se nas proximidades de drenagens, e a zona sedimentos indiferenciados corresponde a maior parte da área de estudo e exibe uma produtividade moderada a baixa (vazão específica média de $1,9 \mathrm{~m} 3 / \mathrm{h} / \mathrm{m}$ ).

Palavras-chave: Aquífero; Subdomínios Hidrogeológicos; Porto Velho.

\begin{abstract}
Hydrogeological studies were developed in Porto Velho's urban area of 117 km², Rondônia, which comprises a porous, heterogeneous and anisotropic hydrogeological system has properties of free aquifers as well as semi-confined aquifers when surrounded by an aquitard. It is constituted by Cenozoic layers with an average thickness of 61,8 meters that overlaps the granitic rocks of the regional basement. The stratigraphy of 189 wells enabled the identification of the porous hydrogeological domain and its lateritic and sedimentary subdomains. The lateritic subdomain (lateritic profile materials) has very low to low productivity and average specific flow rate of $0.26 \mathrm{~m} / \mathrm{h} / \mathrm{m}$. On the other hand, the sedimentary subdomain (sedimentary deposits), according to its productivity, was separated in three hydrogeological zones: aquitard, undifferentiated and alluvial sediments. The alluvial zone has high to very high productivity (average specific flow rate of $11.4 \mathrm{~m}^{3} / \mathrm{h} / \mathrm{m}$ ) and it is located in the eastern portion of the study area. In contrast, the aquitard zone has very low productivity (average specific flow rate of $0.39 \mathrm{~m} 3 / \mathrm{h} / \mathrm{m}$ ) and is located in drainages proximity, and the undifferentiated sediments zone corresponds to most of the study area and displays a low to moderate productivity (specific average flow rate of $1.9 \mathrm{~m}^{3} / \mathrm{h} / \mathrm{m}$ ).
\end{abstract}

Keywords: Aquifer; Hydrogeological Subdomains; Porto Velho.

\section{INTRODUÇÃO}

O sistema aquífero poroso da zona urbana da cidade de Porto Velho e o rio Madeira são as principais fontes de captação de água para o abastecimento da cidade, em que apenas 34,5\% de sua população possui água tratada fornecida pela Companhia de Águas e Esgotos de Rondônia-CAERD (BRASIL, 1996).

Logo, estudos relativos a este aquífero faz-se necessário para o entendimento de sua distribuição, comportamento e produtividade.

Assim, o presente estudo visou a determinação de subdomínios hidrogeológicos, a partir do processamento de dados referentes a declividade, geologia, geomorfologia, perfis estratigráficos e vazão específica de poços tubulares de captação de água subterrânea. 


\section{ÁREA DE ESTUDO}

A área de estudo representada pela zona urbana da cidade de Porto Velho, capital do estado de Rondônia, localiza-se na margem direita do rio Madeira, com área de $117 \mathrm{~km}^{2}$, abrangida pela Amazônia Ocidental, entre as coordenadas geográficas $8^{\circ} 48^{\prime} 46,7^{\prime \prime}$ e

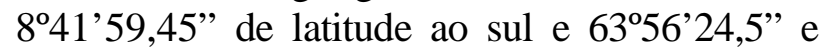
$63^{\circ} 46^{\prime} 55,33^{\prime \prime}$ de longitude oeste (Figura 1).
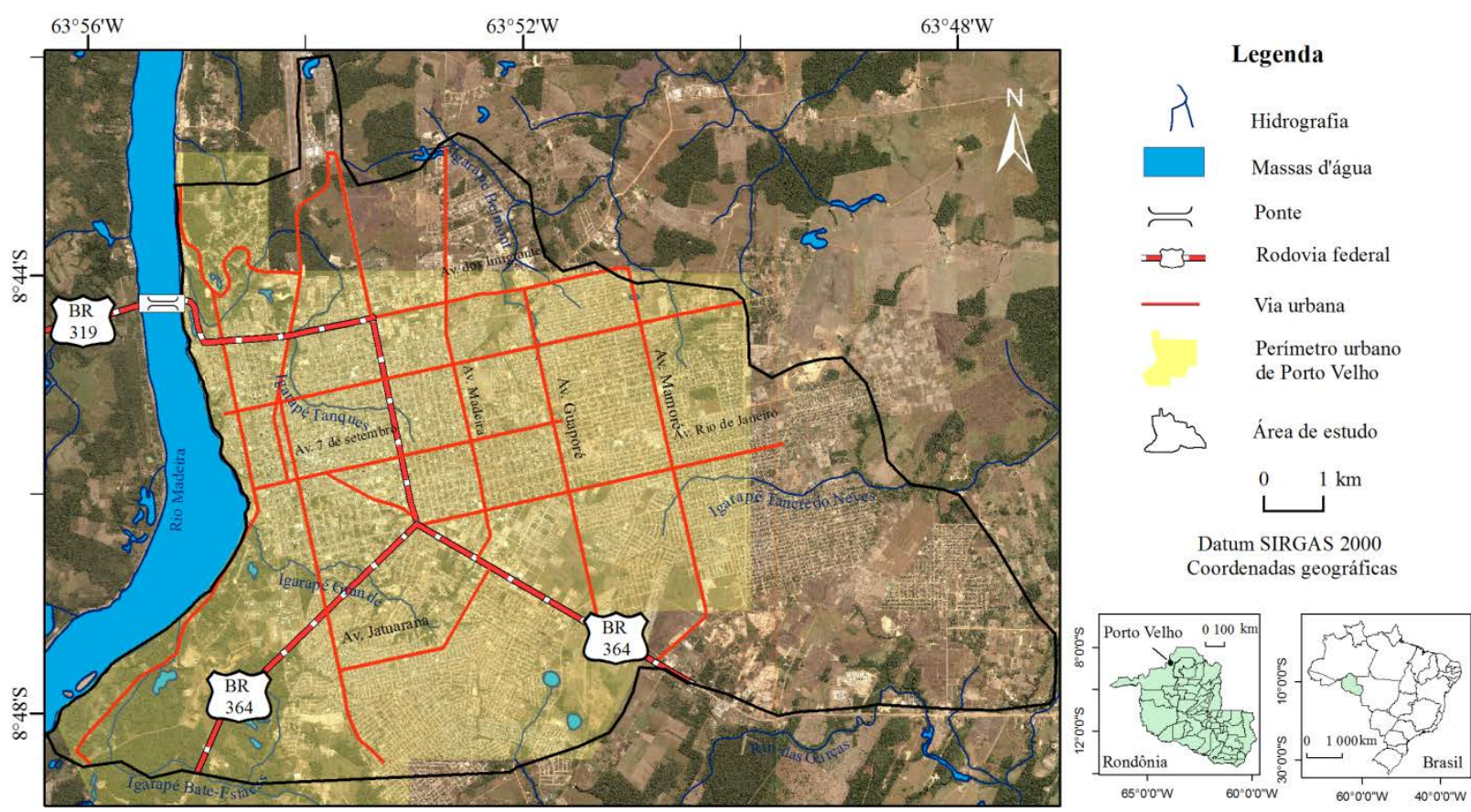

Figura 1 - Mapa de localização da zona urbana da cidade de Porto Velho, Rondônia. Fonte: imagem de satélite Worldview e contorno do perímetro urbano (SEMPLA, 2001).

\section{GEOLOGIA}

O substrato proterozoico sobre o qual se desenvolveram os depósitos sedimentares e o material laterítico no Cenozoico, está representado por granitoides pertencentes a Suíte Intrusiva Serra da Providência, com idade de 1,55 bilhões de anos (Bettencourt et al., 1999) e pela Suíte Intrusiva Santo Antônio, com idade de 1,3 bilhões de anos (Rizzotto et al., 2005, Figura 2).

\section{Embasamento Proterozoico \\ Suíte Intrusiva Providência}

Esta unidade litoestratigráfica (Figura 2) é constituída por granitoides de granulação média a grossa e contemplam as fácies biotita sienogranito, hornblenda-biotita sienogranito, biotita monzogranito com titanita, titanitahornblenda-biotita monzogranito e textura rapakivi, do tipo A e máficas pós-orogênicas (Leal et al., 1976; Bettencourt et al., 1999; Rizzotto et al., 2005).

São rochas com fraturas conjugadas fechadas N50E e foliações incipientes até milonitos bandados devido a transpressão NNW sinistral (Oliveira, 2013).
Payolla (1994) atribuiu aos granitoides da Suíte Intrusiva Santo Antônio três fácies: biotita monzogranito grosso (textura rapakivi e antirapakivi), biotita monzogranito médio e quartzo monzonito. Trata-se de um batólito com afloramentos localizados de modo restrito, próximos às margens do rio Madeira (Quadros \& Rizzotto, 2007), sudoeste da área de estudo.

\section{Cobertura Cenozoica Materiais Lateríticos}

As lateritas de natureza se desenvolveram na área urbana de Porto Velho como indicativos de paleosuperfícies intensamente drenadas, sendo ora bastante resistentes ao intemperismo ora desmanteladas como consequência das condições climáticas subatuais e atuais.

Apresentam perfis incompletos de diferenciação supergênica com partes do horizonte ferruginoso, incluindo suas zonas coesa e incoesa, e/ou partes do horizonte argiloso com suas zonas argilosa vermelha e mosqueada (Nascimento et al., 2012).

Dados detalhados com relação aos materiais lateríticos da cidade de Porto Velho e proximidade são mostrados em Nascimento 
(2012), como segue: os materiais lateríticos da zona coesa possuem baixa densidade, com abundância de estrutura vesicular, poros e paleocondutos de raízes.

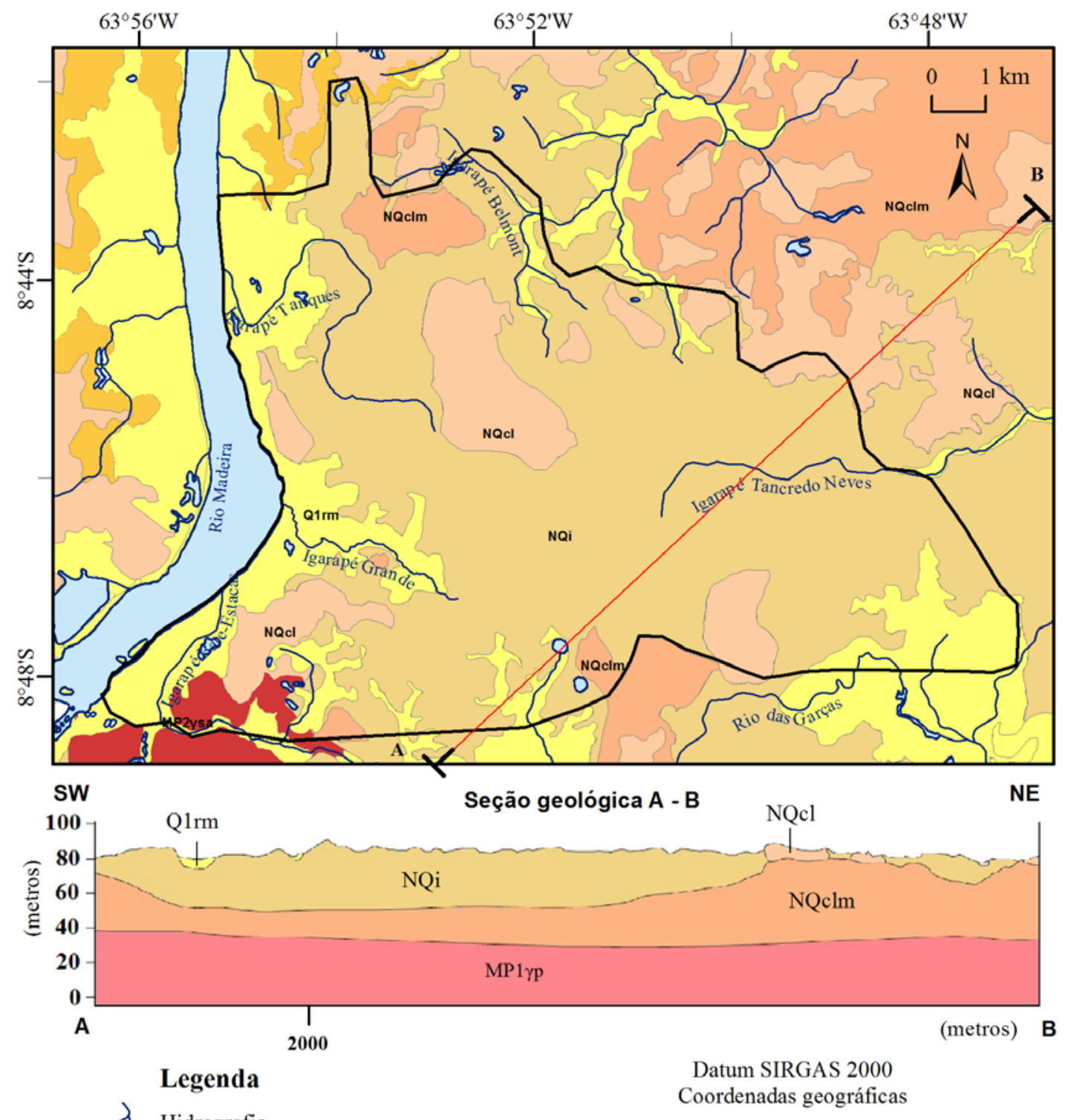

त Hidrografia

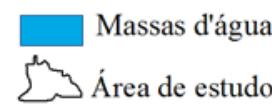

\section{Unidades estratigráficas}

Cobertura cenozoica

Q1rm Depósitos aluvionares

\begin{tabular}{|c|c|}
\hline NQi & Cobertura sedimentar indiferenciada \\
\hline NQcl & Crosta laterítica \\
\hline TQclm & Horizonte mosqueado \\
\hline
\end{tabular}
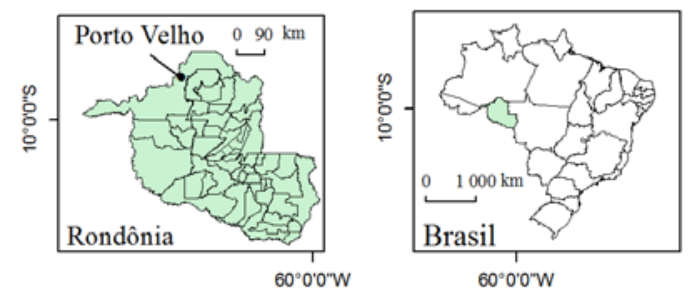

Embasamento proterozoico

MP2 $\gamma$ sa Suíte Intrusiva Santo Antônio

MP1 $\gamma$ p Suite Intrusiva Providência

Figura 2 - Mapa geológico da zona urbana da cidade de Porto Velho, Rondônia. Fonte: modificado de Oliveira (2013).

Seu desmantelamento (zona incoesa) proporcionou a geração predominante de grãos nas frações seixo e grânulo envoltos por argila, com descontinuidade no padrão de distribuição granulométrico que separa a matriz argilosa dos grãos das frações seixo e grânulo, bem como uma gradual redução dos tamanhos dos grãos de 4 a 0,062 mm de diâmetro. 
Sua fração areia mostra a predominância de grãos de laterito, tendo o quartzo e os nódulos de caulinita completando sua composição modal. O material do horizonte argiloso, mesmo possuindo um predomínio da fração argila, apresenta quantidades até $40 \%$ de grãos na fração areia, tanto na zona argilosa vermelha quanto na mosqueada.

A zona argilosa vermelha encontra-se em parte exposta ou abaixo da zona incoesa/coesa, com espessuras superiores a 3 metros. A zona mosqueada localiza-se abaixo da zona argilosa vermelha, com espessura de pelo menos 7 metros, sendo identificadas protocolunas descontínuas e verticalizadas.

São materiais caracterizados por manchas ferruginosas vermelhas centimétricas e irregulares (hematita e goethita), dispersas em uma matriz argilosa esbranquiçada a amarelada (caulinita e gibbsita).

Atualmente, os materiais lateríticos da área de estudo estão sob efeito de intenso intemperismo químico, ou seja, sua exposição ao clima atual proporciona uma situação instável e em processo de eluviação. São saprólitos constituídos por um material argiloso, com relictos de fragmentos ferruginosos de espessura de até 1 metro.

Por outro lado, podem estar cobertos por materiais depositados pela gravidade (colúvios) ou pela dinâmica fluvial atual a subatual do rio Madeira e seus afluentes (depósitos aluvionares), referentes aos sedimentos cenozoicos.

Os materiais lateríticos desempenham papel importante na configuração do relevo local e regional, com feições geomorfológicas da zona aflorante.

As formas de relevo mais exuberantes estão associadas aos lateritos (zona coesa) em função de sua relativa resistência a processos intempéricos atuais. O desenvolvimento de superfícies rebaixadas nas áreas que ocorrem lateritos está associado à paisagem onde afloram materiais ricos em argila (horizonte argiloso) e lateritos desmantelados (zona incoesa).

\section{Sedimentos}

O registro sedimentar da área urbana de Porto Velho refere-se ao reflexo das variações da dinâmica de seu sistema fluvial no Cenozoico, dando origem às unidades geológicas constituídas por sedimentos pliopleistocênicos de difícil individualização (Quadros \& Rizzotto, 2007), denominada de cobertura sedimentar indiferenciada, além de sedimentos aluvionares atuais e subatuais (Scandolara, 1999).

\section{Cobertura sedimentar indiferenciada}

A cobertura sedimentar indiferenciada é a unidade que predomina na área de estudo e foi primeiramente descrita por Scandolara (1999) como sedimentos que ocorrem na margem direita do rio Madeira, com grãos desde a fração cascalho até argila, relacionados aos ambientes aluviais e lacustres. Quadros \& Rizzotto (2007) afirmaram que a unidade geológica possui espessura inferior a 40 metros, desprovida de fósseis, e seus sedimentos foram datados do Plio-Pleistoceno. Oliveira (2013) mencionou que esta unidade é caracterizada por uma superfície aplainada e possui um alto grau de ferruginização. Adamy \& Romanini (1990) descreveram sedimentos desta unidade designando-a como Formação Jaci-Paraná. No entanto, para Quadros \& Rizzotto (2007), a Formação Jaci-Paraná restringe-se à margem esquerda do rio Madeira, limitada pela foz do rio São Lourenço e pela serra Três Irmãos, nas duas margens do rio Jaci-Paraná e à jusante da cachoeira de Jirau.

\section{Depósitos aluvionares}

Os depósitos aluvionares compreendem os sedimentos inconsolidados nos leitos e margens dos canais fluviais atuais, caracterizados notadamente na calha do rio Madeira, além de depósitos de menor envergadura nos seus afluentes.

O rio Madeira destaca-se pela formação de ilhas e barras arenosas em locais de ambiente de deposição. Em canais, são compostos por areias grossas e cascalhos de granulometria variável. Considerando a sazonalidade das estações, verifica-se que no período das cheias ocorre extensa sedimentação nas planícies de inundação, constituídas por siltes e argilas, além das areias silto-argilosas nos diques marginais (Quadros \& Rizzotto, 2007).

\section{HIDROGEOLOGIA}

Dados com relação ao contexto pioneiros de Campos (1998), Morais (1998) e hidrogeológico da cidade de Porto Velho Campos \& Morais (1999). A partir dos tipos encontram-se principalmente nos trabalhos materiais geológicos e estruturas relacionadas à 
porosidade e à permeabilidade (poros e fraturas) no estado de Rondônia, foi possível o reconhecimento das categorias de aquífero poroso e fraturado (Morais, 1998). O referido autor subdividiu essas categorias em seis sistemas aquíferos, são eles: aquíferos intergranulares descontínuos livres a semiconfinados, aquíferos intergranulares contínuos livres, aquíferos fraturados descontínuos livres, aquíferos restritos às zonas fraturadas, aquíferos intergranulares e fraturados livres ou confinados, e aquíferos de baixo potencial hídrico. O aquífero da zona urbana da cidade de Porto Velho enquadra-se na categoria poroso e no sistema de aquíferos intergranulares descontínuos livres a semiconfinados (Morais, 1998). Segundo o autor, a categoria poroso refere-se às características primárias do material geológico, ou seja, a porosidade está diretamente ligada ao armazenamento e percolação da água. Com relação aos aquíferos intergranulares descontínuos, livres a semiconfinados, estes são constituídos por sedimentos terciários e quaternários, aluvionares e coluvionares, de origem fluvial e lacustre. Os sedimentos são mal selecionados com granulometria desde cascalho até argila, inconsolidados a semiconsolidados. Podem ocorrer camadas argilosas ou silto-argilosas com baixa permeabilidade, conferindo-lhes um caráter de semiconfinamento. A produtividade é variada com vazão específica de $36 \mathrm{~m}^{3} / \mathrm{h} / \mathrm{m}$ até poços improdutivos, com vazão específica média de $1 \mathrm{~m}^{3} / \mathrm{h} / \mathrm{m}$. A transmissividade tem valor médio de $6,03 \times 10^{-4} \mathrm{~m}^{2} / \mathrm{s}$, com valores que variam de $6,6 \times 10^{-6}$ a $4,27 \times 10^{-3} \mathrm{~m}^{2} / \mathrm{s}$.

Campos (1998) elaborou a avaliação preliminar sobre o potencial hidrogeológico da cidade de Porto Velho com base em 8 poços tubulares e definiu que a vazão específica varia de 0,11 a $5,3 \mathrm{~m}^{3} / \mathrm{h} / \mathrm{m}$, além de verificar que o aquífero é heterogêneo e composto por uma camada de 50 metros de sedimentos. Campos \& Morais (1999) caracterizaram a morfologia do aquífero com base em 51 poços tubulares e concluíram que a mesma é constituída por uma camada de areia média a grossa, com espessura de 12 a 32 metros, largura de 1.500 a 2.500 metros e comprimento de 9.000 metros com direção NW-SE, associada a um paleocanal. Ressaltaram, ainda, que o aquífero possui lentes de laterita e uma camada de argila no topo sugerindo o aquífero tipo confinado, e que os locais onde o aquífero aflora seria sua área de recarga.

\section{MATERIAIS E MÉTODOS}

Realizou-se o levantamento, no domínio hidrogeológico poroso, dos parâmetros hidrodinâmicos, de testes de bombeamento e de perfis estratigráficos (Figura 3) de, respectivamente, 185, 189 e 16 poços tubulares de captação de água subterrânea (CPRM, 1997, com atualização permanente; CAERD, 2004), das curvas de nível do terreno com equidistância de 1 metro (SEMPLA, 2001), dos dados bibliográficos geológicos, geomorfológicos e hidrogeológicos nas bibliotecas da Fundação Universidade Federal de Rondônia - UNIR, Secretaria do Desenvolvimento Ambiental do Estado de Rondônia - SEDAM, Serviço Geológico do Brasil - CPRM e sítios eletrônicos acadêmicos. Foram utilizados GPS, câmera fotográfica, martelo e lupa de bolso, em campo, e os programas ArcGis 10.1 (ESRI, 2012), Word e Excel, em escritório.

Com os dados de curvas de nível gerou-se o modelo digital de terreno - MDT e declividade com a utilização da projeção geográfica e o datum SIRGAS 2000, conforme a orientação do IBGE (2005).

Em seguida, a fim de mapear os subdomínios do domínio hidrogeológico poroso da zona urbana do município de Porto Velho, relacionou-se a topografia (MDT e declividade) com a geologia (perfil estratigráfico). Posteriormente, os dados de vazão específica de 185 poços foram agrupados em 6 classes, conforme a classificação de Diniz et al. (2012), a fim de caracterizar a produtividade da área de estudo.

Para a individualização dos subdomínios em aquífero, aquitardo e aquífugo, respaldados por Custodio \& Llamas (1976) e Fetter (2001), relacionou-se a composição (estratigrafia) com os parâmetros hidraúlicos, (vazões específicas, permeabilidade, condutividade hidráulica e produtividade), conforme Diniz et al., 2012. 

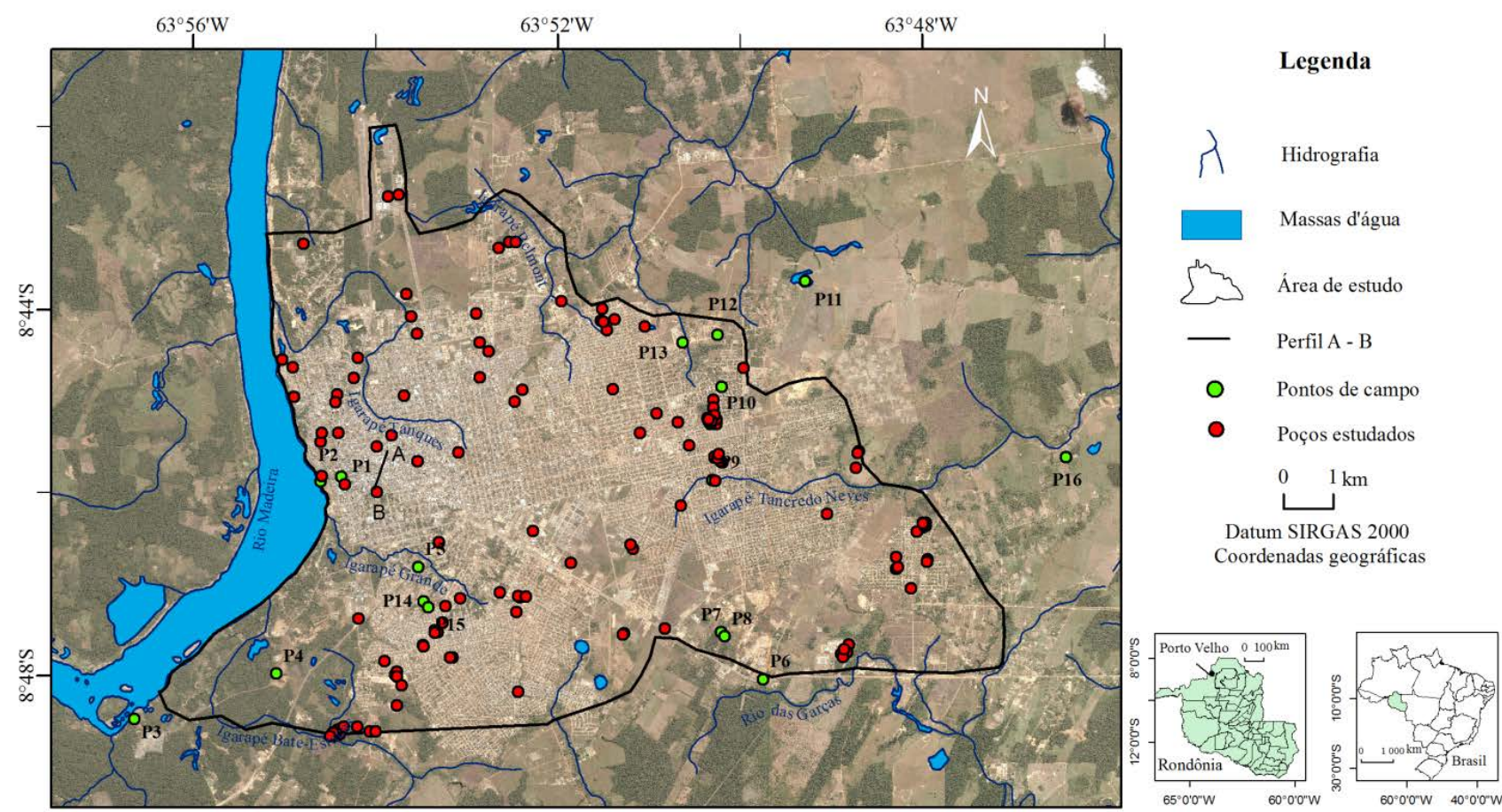

Figura 3 - Mapa de localização dos poços estudados da zona urbana da cidade de Porto Velho, Rondônia Fonte: imagem de satélite Worldview (SEMPLA, 2001) e poços (CPRM, 1997, com atualização permanente).

Desta forma, com o cruzamento destas informações, foi possível a identificação de locais de maior e menor produtividade, os quais foram utilizados na determinação das zonas dos subdomínios do domínio hidrogeológico poroso.

O problema mais relevante na busca do detalhamento com base nas descrições desses poços tubulares foi em relação aos materiais lateríticos, pois, muitas vezes não foi descrito o seu estado de coesão. Para separá-las utilizouse o critério de que nas cotas mais elevadas do terreno há a presença de crosta laterítica coesa e nas porções mais baixas, lateritas incoesas, como foi verificado nos trabalhos de campo. Dessa forma, valeu-se desse critério para separar as lateritas em coesas, localizadas nas cotas mais elevadas, das lateritas incoesas e materiais argilosos mosqueados, localizados nas cotas menos elevadas.

Por fim, realizou-se o reconhecimento geológico e geomorfológico com trabalhos de campo, incluindo registros fotográficos dos subdomínios em duas etapas de campo que contemplaram um total de 16 pontos visitados.

\section{RESULTADOS E DISCUSSÕES}

\section{Modelo Digital de Terreno e Declividade}

O terreno da área de estudo é delineado por elevações máximas de 110 metros e mínimas de 46 metros, com cota média de 82,5 metros e uma amplitude altimétrica de 64 metros (Figura 4).

As declividades abaixo de $3 \%$, principalmente na porção centro-leste, configuram o relevo aplainado (Figura 5). A partir da cota 90 metros, o relevo torna-se forte ondulado com declividades superiores a $20 \%$, destacado por colinas, sobretudo na porção sudeste, sudoeste e centro-norte da área de estudo. Essas feições positivas assimétricas com amplitude de 20 metros formam corpos alongados de até 2.000 metros de comprimento por até 500 metros de largura, com orientação preferencial NNW e subordinadamente NNE. Na porção oeste da área de estudo, próximo às drenagens, o relevo é do tipo forte montanhoso com declividades superiores a $75 \%$.

Provavelmente as feições positivas do relevo, formadas pelo perfil laterítico, podem ter sido delineadas a partir da erosão pluvial que se aproveitou das feições negativas (por exemplo, fraturas NNW), facilitando o fluxo aquoso.

\section{Subdomínios Hidrogeológicos}

O domínio hidrogeológico poroso é constituído pela cobertura cenozoica que contempla materiais lateríticos (subdomínio hidrogeológico laterítico), bem como 
sedimentos indiferenciados e aluvionares (subdomínio hidrogeológico sedimentar), como mostra o perfil topográfico e estratigráfico da Figura 6.

Em um mesmo subdomínio hidrogeológico são identificadas diferentes zonas com base na classificação de produtividade dos poços de Diniz et al. (2012), estratigrafia e topografia, conforme mostra o mapa de subdomínios da Figura 7.
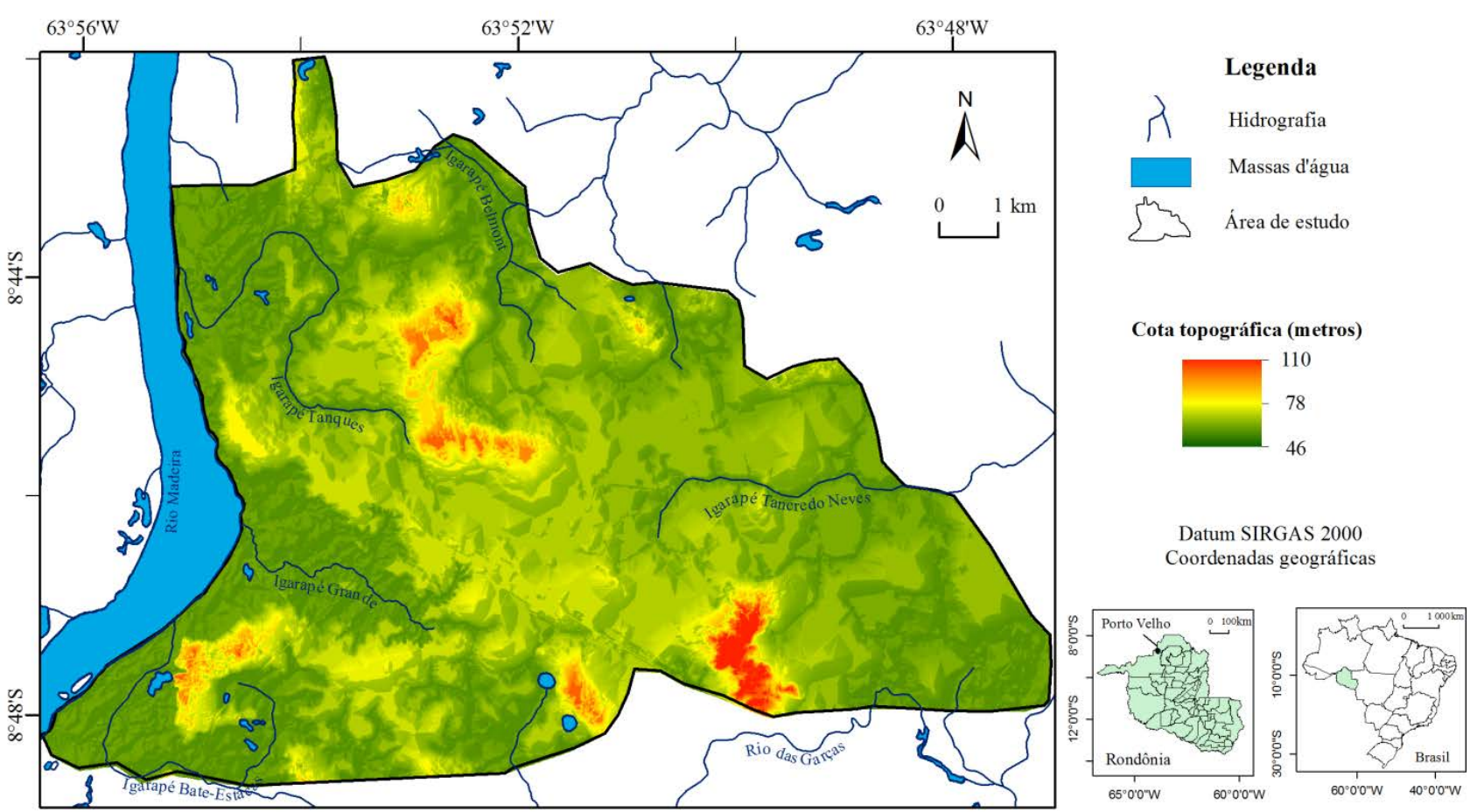

Figura 4 - Modelo digital de terreno da zona urbana da cidade de Porto Velho, Rondônia. Base de dados: SEMPLA (2001).
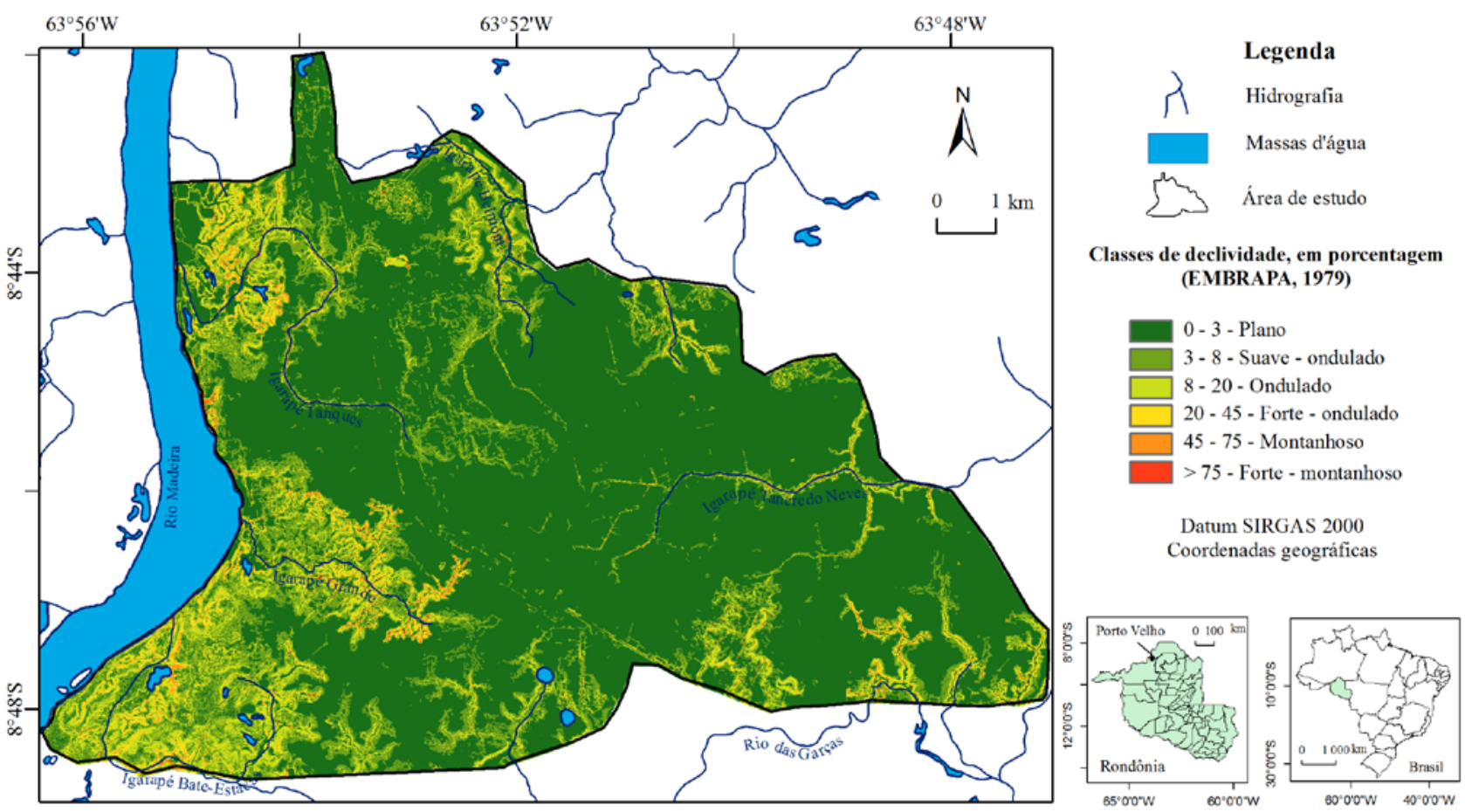

Figura 5 - Mapa de declividade da zona urbana da cidade de Porto Velho, Rondônia. Base de dados: SEMPLA (2001). 


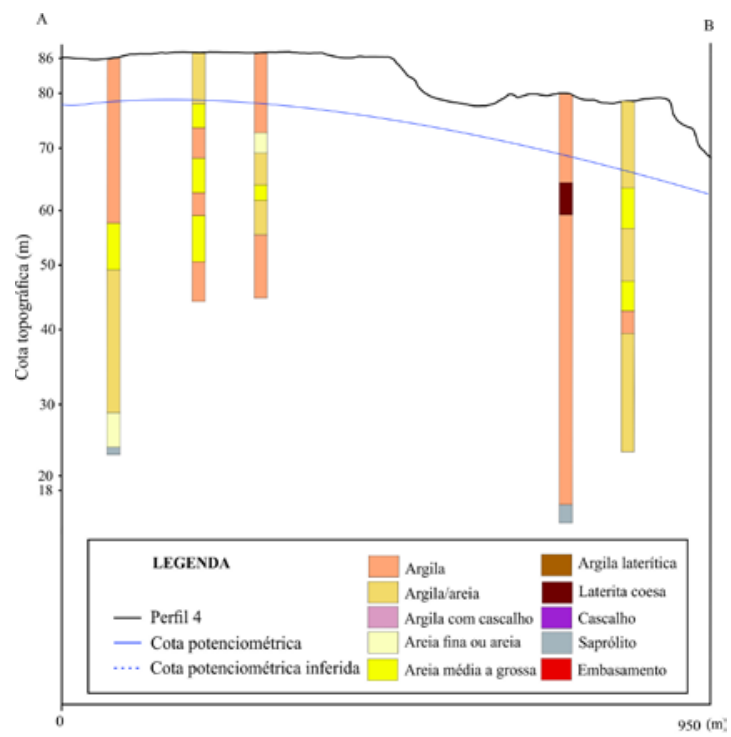

Figura 6 - Perfil topográfico e estratigráfico A-B com indicação do nível estático. Base de dados: CPRM, 1997, com atualização permanente.
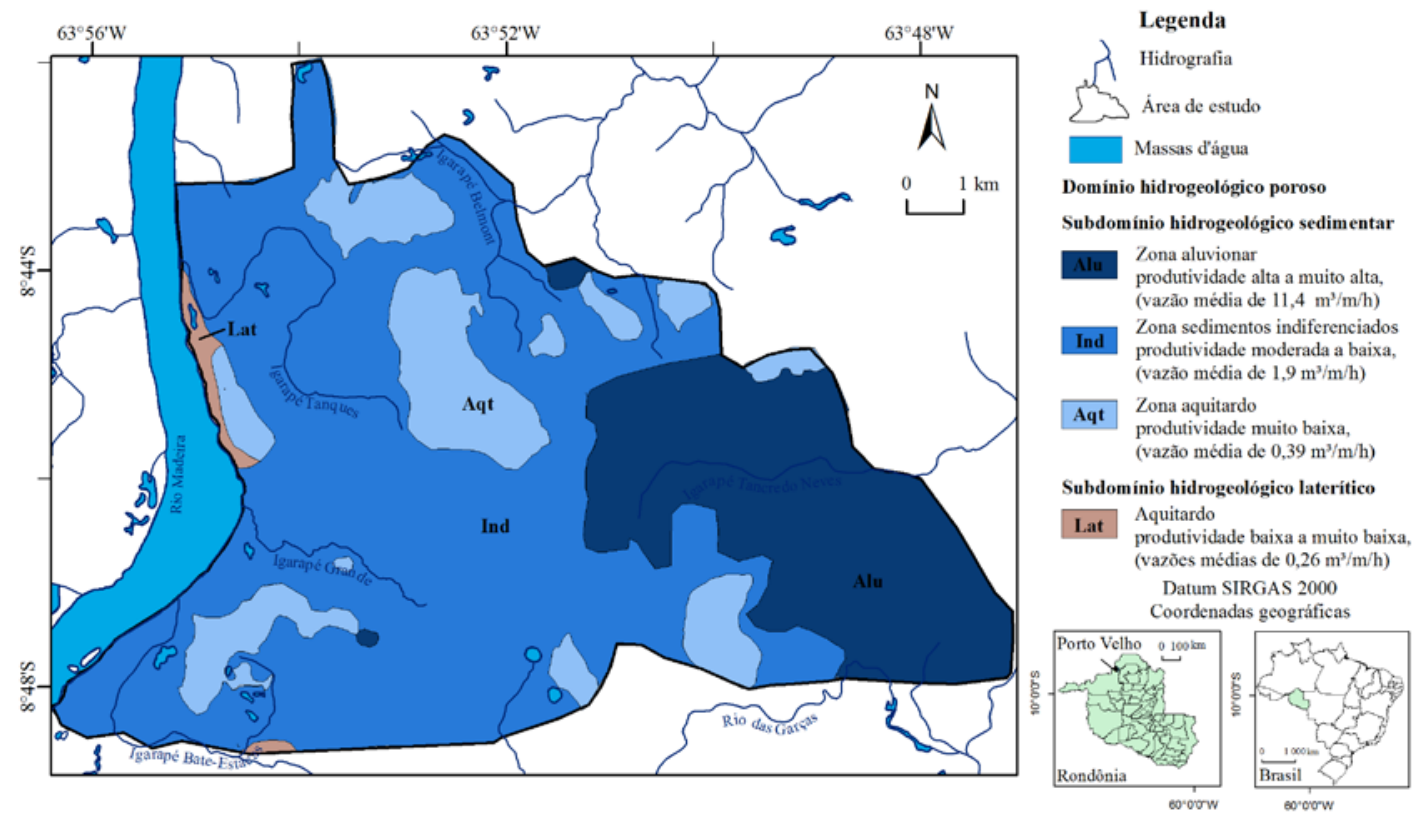

Figura 7 - Mapa de subdomínios hidrogeológicos da zona urbana da cidade de Porto Velho, Rondônia. Base de dados: CPRM, 1997, com atualização permanente.

Subdomínio hidrogeológico laterítico - O subdomínio hidrogeológico laterítico abrange o perfil laterítico imaturo formado pelo horizonte argiloso (na base) e horizonte ferruginoso ou zona coesa/incoesa (no topo). Neste subdomínio são identificados aquitardos e aquíferos pobres, livres, podendo ter porções do aquíferos semiconfinadas.

A partir da cota 87 metros, o relevo se destaca com colinas espraiadas ou suaves platôs alongados na direção NW/SE, preferencialmente, e NE/SW, subordinados, que são delimitados por declividades elevadas.
Esses arranjos morfológicos estão relacionados à resistência de processos intempéricos subatuais onde é exposto o horizonte ferruginoso (zona coesa), descrito por Nascimento et al. (2012).

A zona coesa é encontrada em cotas superiores a 60 metros, com espessura média de 5 metros (mín. de 3,7 e máx. de 9,3 metros).

É formado por nódulos e pisólitos milimétricos a centimétricos, em estruturas colunares (Figura 8) cimentadas fortemente ou fracamente por material argiloso, como mencionado por Nascimento et al. (2012). 


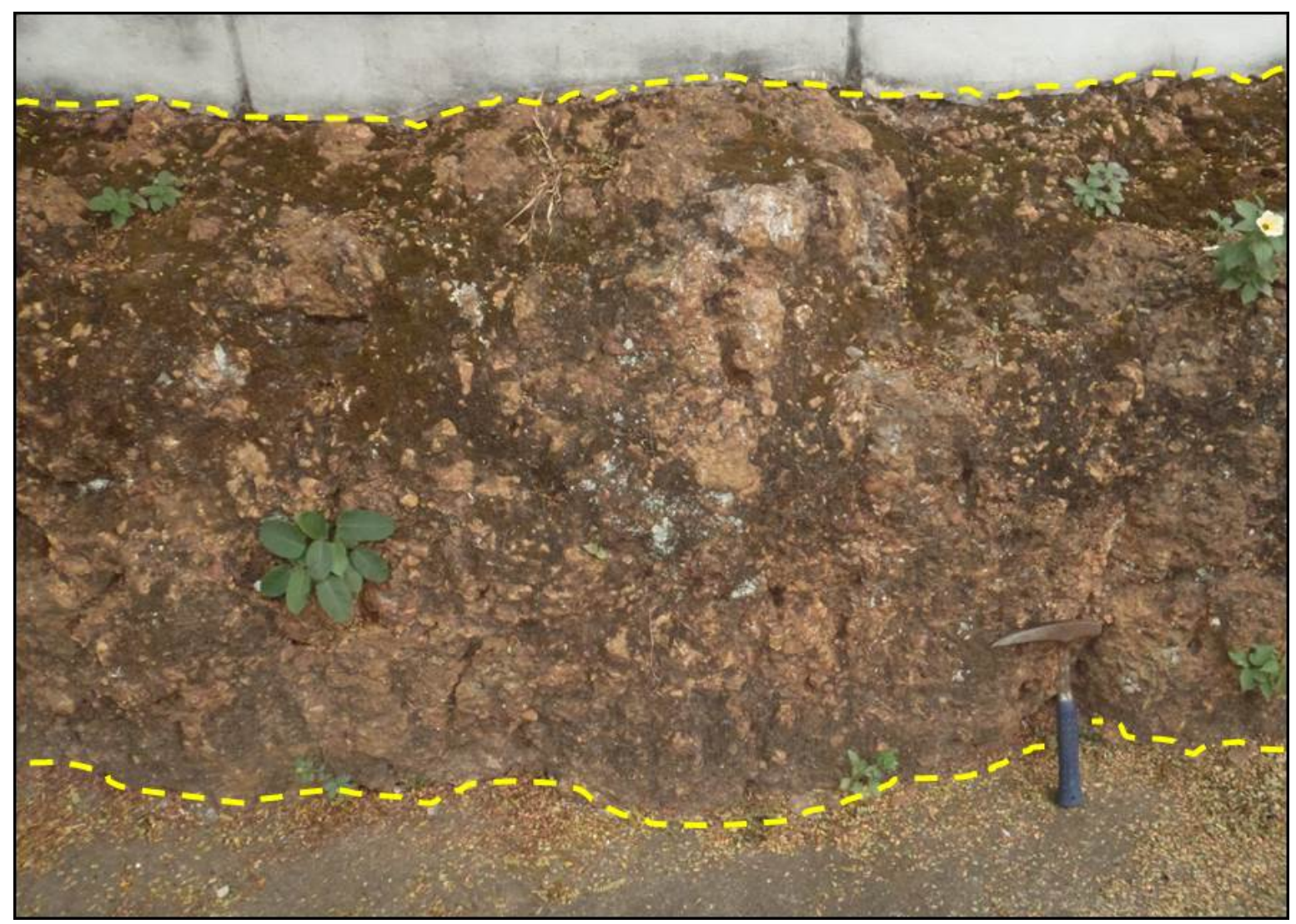

Figura 8 - Detalhe (linha amarela pontilhada) para a laterita coesa, bem cimentada in situ. Na porção superior da laterita coesa encontra-se o prédio da Universidade Federal de Rondônia - Centro, e na porção inferior, piso de cimentocalçada. Localização: Fundação Universidade Federal de Rondônia - UNIR - Centro. Ponto 1, cota 79 metros, 10/09/2016.

O horizonte ferruginoso - zona coesa - pode estar sobreposto pelo produto do seu próprio desmantelamento in situ - zona incoesa.

Para Nascimento et al. (2012) as lateritas incoesas são constituídas predominantemente por grãos nas frações seixo, grânulo e areia (87\%), bem como de argila de modo subordinado, além de traços de silte.

No entanto, as lateritas incoesas também estão distribuídas em cotas menos elevadas, representadas por depósitos coluvionares pertencentes ao subdomínio sedimentar.

O horizonte argiloso se encontra coberto por lateritas coesas e incoesas, próximo à cota 94 metros (Figura 9), sedimentos aluvionares e solos indiscriminados.

Em cotas próximas a 83 metros, o horizonte argiloso mosqueado aflora. Em subsuperfície, sua espessura varia de 20 a 55 metros (média de 40 metros) e sua base faz contato irregular com o saprólito, produto da decomposição do embasamento granítico regional, em cotas topográficas que variam de 7 a 52 metros (média de 29,8 metros).

O horizonte argiloso é composto

basicamente por argila e areia fina, o qual pode ser dividido em duas zonas que se diferenciam pela coloração (branca, cinza, vermelha levemente roxa) e pela proporção de areia e argila, denominadas zona argilosa vermelha e mosqueada (Nascimento et al., 2012).

Para os autores, a zona argilosa vermelha pode conter $60 \%$ de argila e teores próximos a $40 \%$ de grãos nas frações areia e grânulo. No que tange à zona mosqueada, esta pode conter $74,5 \%$ de argila e $24,6 \%$ de areia e grânulo, além de apresentar manchas ferruginosas vermelhas centimétricas e irregulares (hematita e goethita), dispersas em uma matriz argilosa esbranquiçada a amarelada (caulinita).

Devido a esta granulação, a sua condutividade hidráulica pode variar de $10^{-3}$ a $10^{-7}$ $\mathrm{cm} / \mathrm{s}$, onde as porções menos permeáveis indicam os aquitardos e as mais permeáveis os aquíferos pobres. Estes aquíferos do subdomínio hidrogeológico laterítico possuem caráter livre, mas quando sobrepostos por lateritas coesas podem apresentar o caráter semiconfinado. 


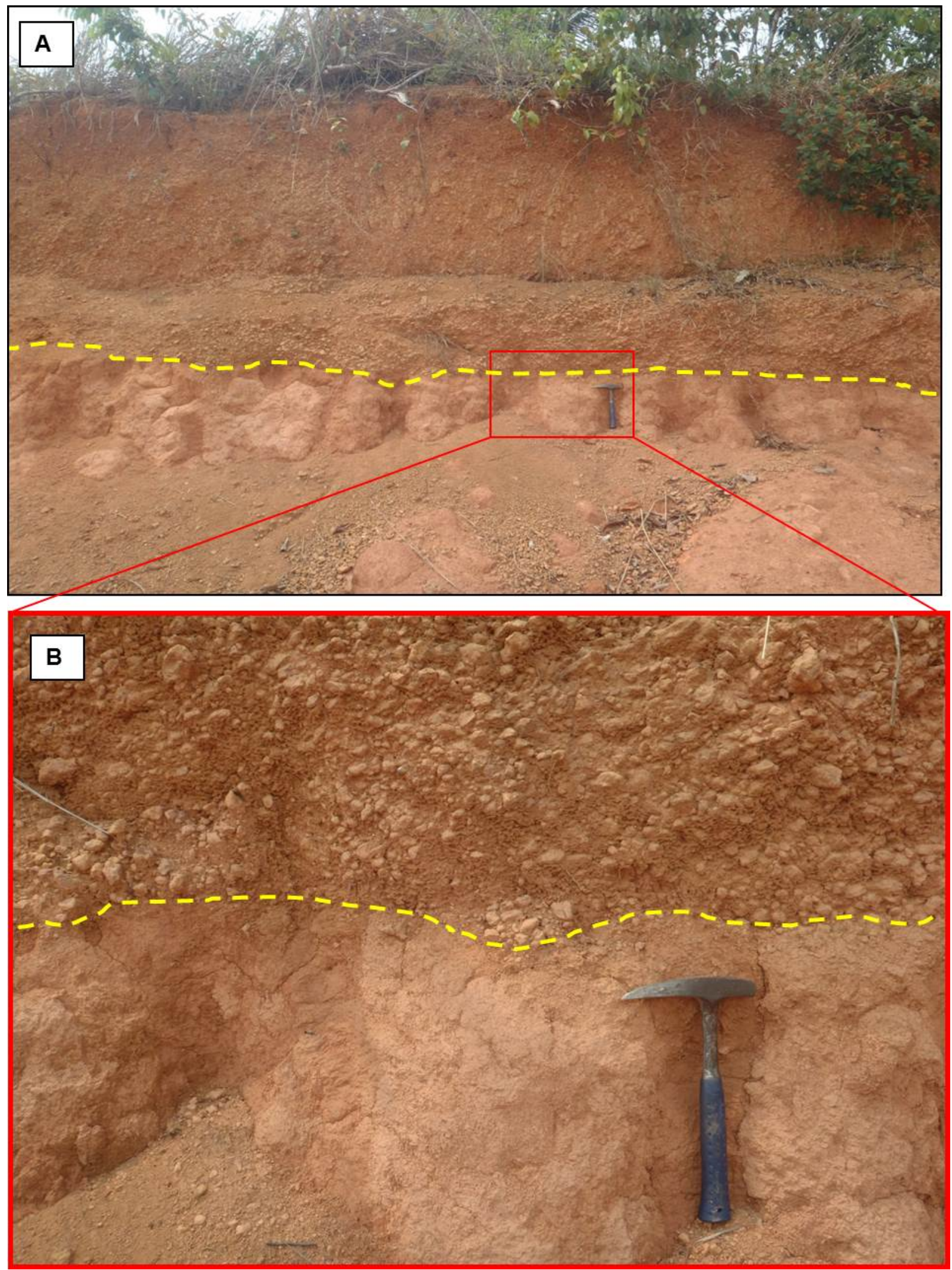

Figura 9 - Visão geral do afloramento (A) e detalhe (linha amarela pontilhada) do contato do horizonte mosqueado (abaixo) com a laterita incoesa (B). Localização: próximo à Faculdade de Rondônia - Faro. Ponto 7, cota 94 metros, 10/09/2016.

Os aquíferos do subdomínio hidrogeológico laterítico exibem uma produtividade muito baixa a baixa, com vazões específicas de 0,03 a

x $\quad 0,5 \quad \mathrm{~m}^{3} / \mathrm{h} / \mathrm{m} \quad$ (média de $0,26 \quad \mathrm{~m}^{3} / \mathrm{h} / \mathrm{m}$ ), consequentemente, são indicados para captação de água para consumo local (Diniz et al., 2012). 
As maiores vazões específicas podem estar relacionadas com o maior teor de areia da zona argilosa vermelha.

Subdomínio hidrogeológico sedimentar - Na área de estudo, o subdomínio hidrogeológico sedimentar encontra-se predominante em superfície e engloba as unidades estratigráficas referentes à cobertura sedimentar indiferenciada e depósitos aluvionares. Situa-se em cotas inferiores a 89 metros, onde o relevo é plano a levemente ondulado, porém, próximo às drenagens sua declividade é mais acentuada. Este subdomínio hidrogeológico é heterogêneo e anisotrópico em função da presença de camadas arenosas descontínuas e de variadas granulações (fina, média e grossa) envoltas por frações menores (argila e silte), o que implica em distintos comportamentos hidráulicos.

Os depósitos aluvionares são identificados em camadas descontínuas ou lentes métricas (espessura média de 13,5 metros), formados por areia fina a grossa com porções de conglomerados, os quais formam os aquíferos livres. No entanto, quando essas camadas são envoltas por materiais de granulação mais fina, como argila e silte, o aquífero passa a apresentar caráter semiconfinado. De acordo com Suguio (2003), as frações mais grossas podem corresponder a um ambiente de alta energia relacionado ao preenchimento de canais ativos de leitos de rios e as frações finas podem indicar a sedimentação em planícies de inundação ou canal abandonado, apontando um ambiente de baixa energia.

Esses depósitos podem estar associados à sedimentação em canais fluviais e planícies de inundação subatuais e atuais, do leito do rio Madeira (porção oeste da área de estudo) e seus afluentes, como os igarapés Belmont e Tanques (norte), rio das Graças e igarapé Tancredo Neves (leste), bem como os igarapés BateEstacas (sul) e Grande (oeste).

Nos depósitos aluvionares há a ocorrência de estruturas sedimentares (estratificação cruzada) em camadas arenosas, típicas de ambiente fluvial (Figura 10).

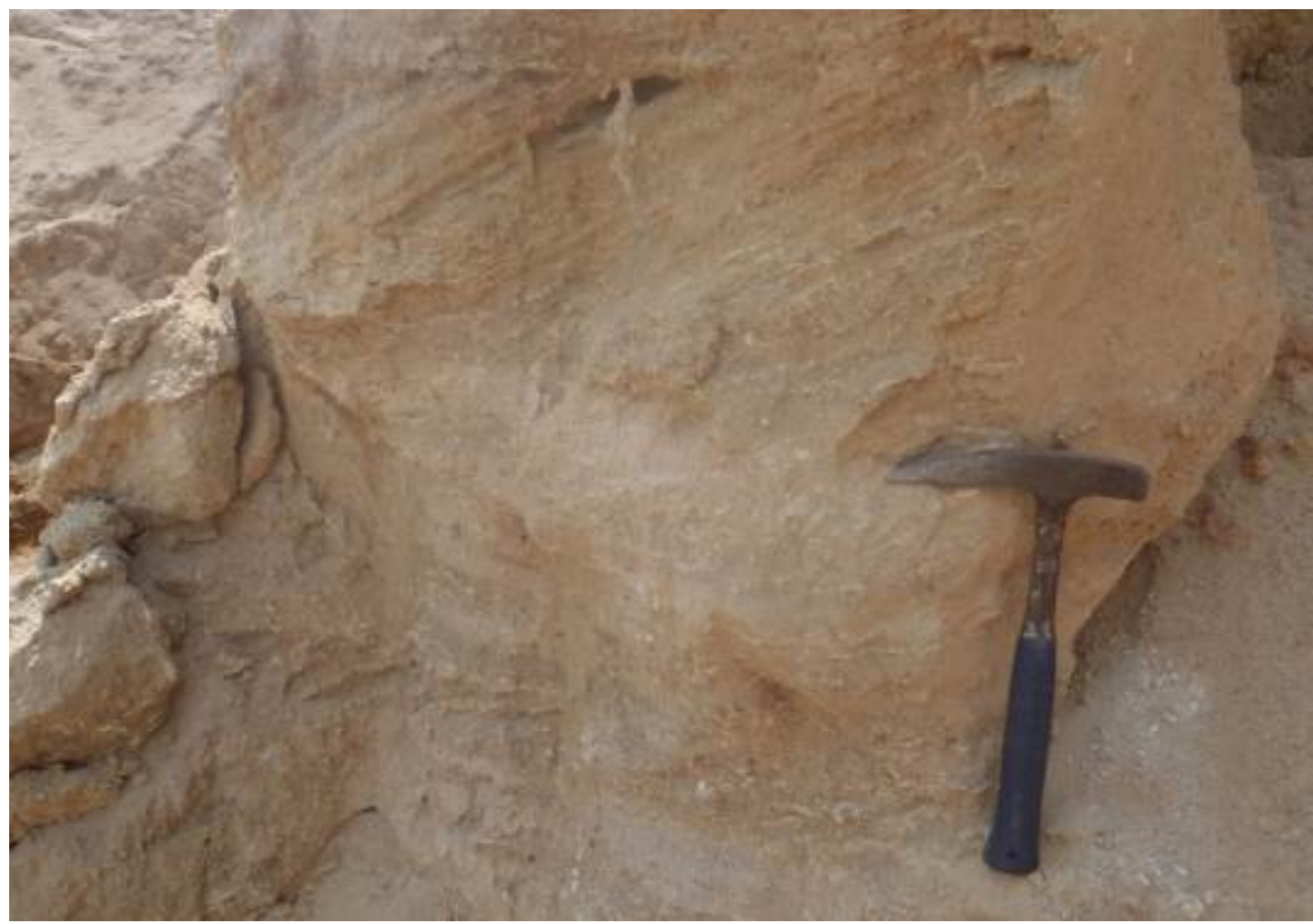

Figura 10 - Estrutura sedimentar de ambiente fluvial (estratificação cruzada) em um depósito arenoso (Ponto 16, 17/09/2016). Localização: Estrada dos Piriquitos, cava de areia Piauí.

O subdomínio hidrogeológico sedimentar encontra-se sobreposto às rochas do embasamento granítico regional na cota topográfica média de 18,03 metros (mínima de 10 e máxima 30 metros) a uma profundidade média de 65,7 metros (mínima de 54 e máxima de 74 metros).

Em cotas próximas de 57 metros, no entorno de igarapés, os depósitos aluvionares sobrepõem os coluvionares (Figura 11). 


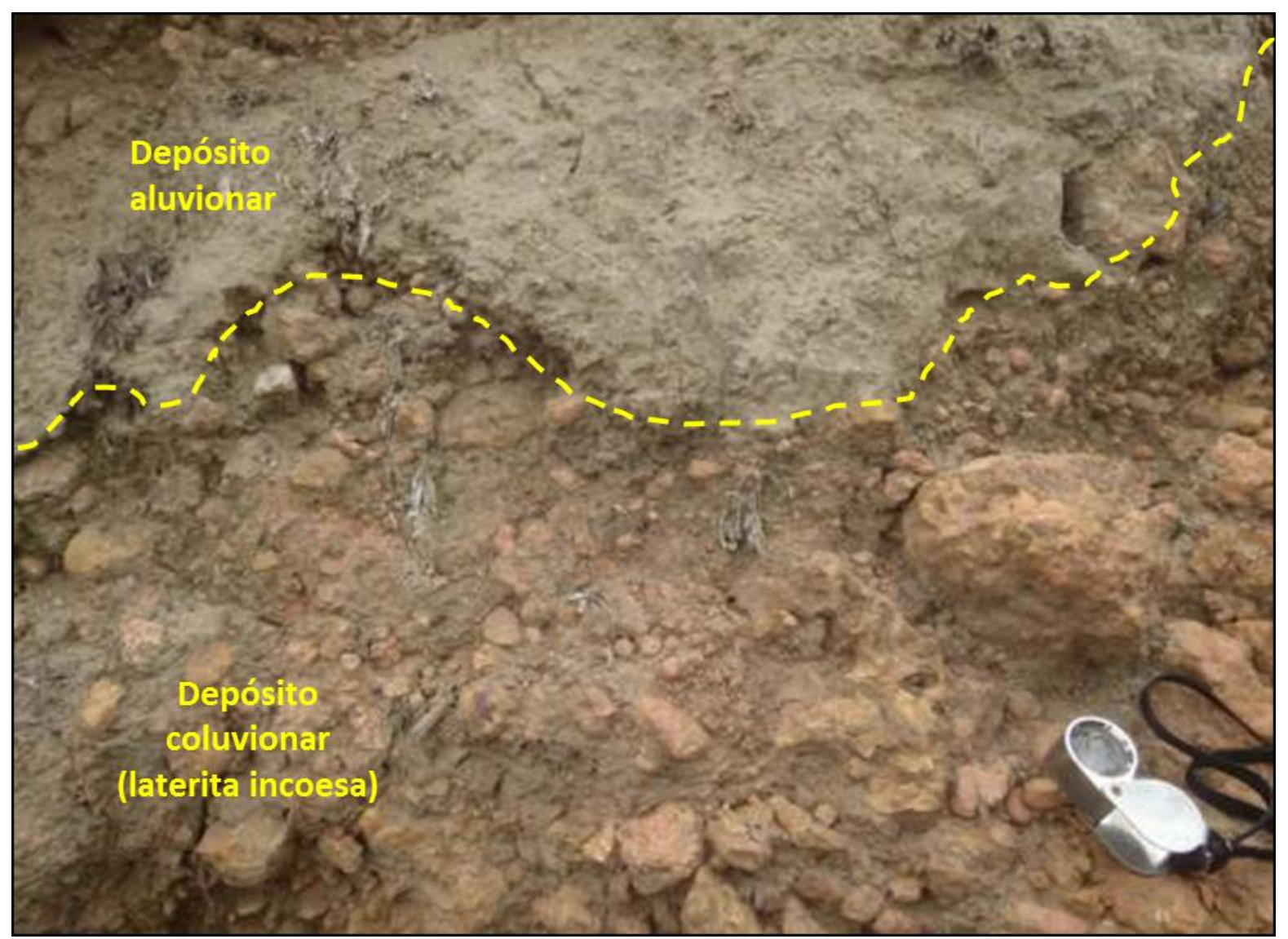

Figura 11 - Contato (linha amarela pontilhada) entre o depósito aluvionar do rio Madeira (acima) com o depósito de colúvio formado por lateritas incoesas (abaixo). Localização: próximo à Estação Ferroviária Madeira-Mamoré. Ponto 2, cota 56,6 metros, 10/09/2016.

Os depósitos aluvionares sobrepõem os materiais argilosos da zona mosqueada do subdomínio hidrogeológico laterítico, próximos à cota topográfica de 70 metros e/ou profundidade de 15 metros (Figura 12).

Os depósitos de colúvios correspondem aos materiais de diferentes granulações e composição, desde argila até cascalho. São provenientes do transporte gravitacional de lateritas incoesas, materiais do horizonte argiloso mosqueado, sedimentos aluvionares pretéritos ou materiais argilosos indiscriminados para porções mais rebaixadas do terreno. Este subdomínio hidrogeológico sedimentar exibe as zonas aquitardo, sedimentos indiferenciados e aluvionar. Teve como base a classificação de produtividade de Diniz et al. (2012) e o intervalo de condutividade hidráulica correspondente as granulações estabelecidas por Custodio \& Llamas (1976).

Zona aquitardo - A zona aquitardo, localizada nas proximidades de drenagens nas porções noroeste e sudoeste da área de estudo, é constituída predominantemente por argila ou argila com areia, além de camadas delgadas de areia média a grossa e, por vezes, laterizadas. Considerando a sua baixa permeabilidade, produz vazões específicas de 0,06 a 0,39 $\mathrm{m}^{3} / \mathrm{h} / \mathrm{m}$ (média de $0,18 \mathrm{~m}^{3} / \mathrm{h} / \mathrm{m}$ ).

São vazões específicas indicadas para o abastecimento restrito (Diniz et al., 2012) e implicam em uma produtividade baixa a muito baixa.

Os aquitardos estão presentes em menor proporção nas zonas de sedimentos indiferenciados e aluvionares que perfazem camadas com espessura média de 12,7 metros, intercalados com os aquíferos.

Diante disso, os aquitardos podem atribuir o caráter semiconfinado para os aquíferos e a diminuição da produtividade dos poços do subdomínio hidrogeológico sedimentar.

Zona sedimentos indiferenciados - A zona sedimentos indiferenciados é constituída por materiais de permeabilidade predominantemente moderada, formada por depósitos de areia, silte e argila, além de lateritas incoesas intercaladas. Sua condutividade hidráulica varia de $10^{-5}$ e $10^{-3} \mathrm{~cm} / \mathrm{s}$, indicando aquíferos pobres. 
No entanto, por se tratar de uma zona heterogênea, podem ocorrer, no aquífero, porções localizadas de maior ou menor permeabilidade, devido ao aumento ou diminuição da condutividade hidráulica e vazão específica. Esta zona é predominante na área de estudo, em superfície e em subsuperfície, abrangendo cotas intermediárias (menores que 82,5 metros). As vazões específicas variam de
0,02 a 7,5 m³/h/m (média de 1,9 m³/h/m), indicando uma produtividade muito baixa a moderada.

Os poços com vazão específica maior que 1 $\mathrm{m}^{3} / \mathrm{h} / \mathrm{m}$ são indicados para abastecimento local de pequenas comunidades (Diniz et al., 2012).

A zona sedimentos indiferenciados exibe caráter livre a semiconfinado e sobrepõe a zona mosqueada do subdomínio laterítico.
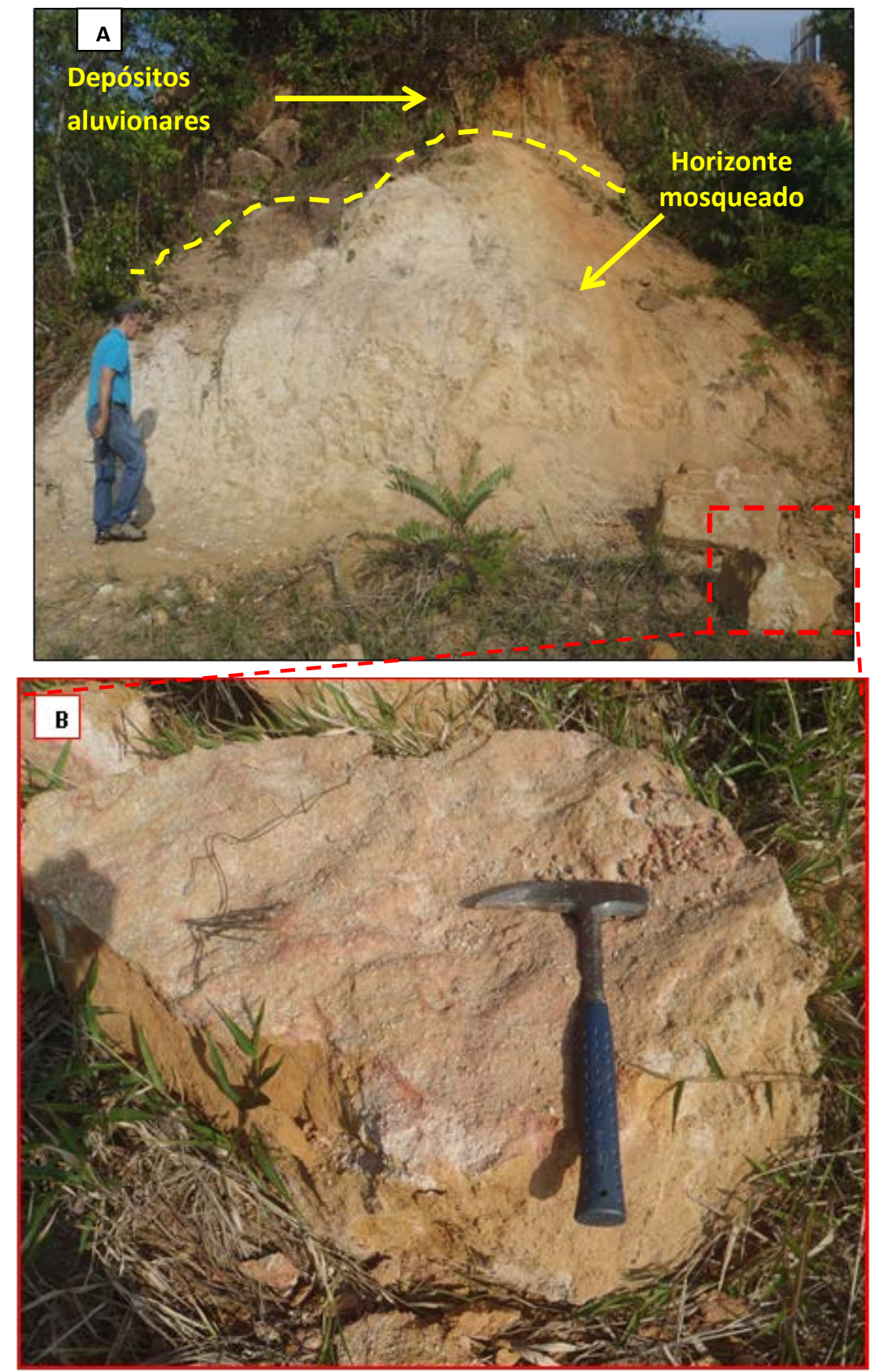

Figura 12 - Contato entre o depósito aluvionar com o horizonte mosqueado (A). Depósito de areia coesa, mal selecionada, levemente ferruginizada (B). Ponto 14, cota 71 metros, 17/09/2016. 
Zona aluvionar - A zona aluvionar apresenta-se de modo heterogêneo e anisotrópico, formada por camadas arenosas com grãos mal selecionados, interdigitadas por sedimentos argilosos.

As vazões específicas variam de 0,6 a 28 $\mathrm{m}^{3} / \mathrm{h} / \mathrm{m}$ (média de $11,4 \mathrm{~m}^{3} / \mathrm{h} / \mathrm{m}$ ), as quais estão relacionadas com a natureza da sua composição, composta por sedimentos com características hidrogeológicas que variam de aquitardos até aquíferos excelentes e de caráter livre a semiconfinado. Devido à significativa espessura de material arenoso (média de 15 metros), suas camadas configuram em um aquífero de alta produtividade. Os poços com vazões específicas superiores a $2 \mathrm{~m}^{3} / \mathrm{h} / \mathrm{m}$ representam aquíferos bons com produtividade alta e são indicados para o abastecimento de pequenas comunidades, segundo os critérios de Diniz et al. (2012). No entanto, os poços com vazões específicas superiores a $4 \quad \mathrm{~m}^{3} / \mathrm{h} / \mathrm{m}$ indicam uma produtividade muito alta, ou seja, são aquíferos excelentes que podem ser utilizados para o abastecimento de cidades e na irrigação (Diniz et al., 2012).

A zona aluvionar localiza-se em cotas inferiores a 82,5 metros, porção leste da área de estudo. Cerca de 23 poços desta zona interceptam rochas do embasamento granítico regional e apresentam espessura total de areia de 3 a 44 metros (média de 19,1 metros), sendo poços constituídos em média por $24 \%$ de sedimentos na fração areia. Campos \& Morais (1999) concluíram que áreas contíguas a área deste estudo é constituída por camadas de espessura de 12a 32 metros.

\section{CONCLUSÕES}

O sistema aquífero poroso inserido na zona urbana da cidade de Porto Velho trata-se de aquífero heterogêneo, anisotrópico e livre a semiconfinado, em função da distribuição de suas camadas e composição (argila a cascalho, bem como laterita incoesa e coesa).

As características do sistema aquífero poroso refletem uma produtividade variada, desde muito baixa (zona aquitardo - subdomínio hidrogeológico laterítico e sedimentar) a muito alta (zona aluvionar - subdomínio hidrogeológico sedimentar), mas com predomínio da produtividade moderada (zona sedimentos indiferenciados - subdomínio hidrogeológico sedimentar).

A zona sedimentos indiferenciados é indicada para o abastecimento local, devido sua vazão específica média de $1,9 \mathrm{~m} 3 / \mathrm{h} / \mathrm{m}$, já a zona aluvionar, porção leste da área de estudo, apresenta produtividade com vazão específica média de $11,4 \mathrm{~m}^{3} / \mathrm{h} / \mathrm{m}$, indicada para abastecimento de pequenas comunidades da cidade de Porto Velho. No entanto, há áreas mais restritas indicadas para explotação local, como é o caso do subdomínio hidrogeológico laterítico em que a vazão específica média é de $0,26 \mathrm{~m}^{3} / \mathrm{h} / \mathrm{m}$.

Apesar de ser, majoritariamente, um aquífero produtivo, o gradativo aumento de áreas impermeáveis na cidade de Porto Velho (calçadas cimentadas e vias públicas asfaltadas), coexistindo com materiais de permeabilidade moderada a baixa da cobertura cenozoica e a carência de captação de esgoto podem contribuir para diminuição quantitativa e qualitativa das águas subterrâneas.

Contudo, vislumbra-se a necessidade de construções de mais parques e, principalmente, calçadas verdes (grama ou brita) para a melhoria dos locais de recarga do aquífero, bem como a diminuição do escoamento horizontal das águas pluviais que, por vezes, acumulam na superfície e causam alagamentos semelhantes ao ocorrido em 2013. Além disso, admite-se, também, a necessidade de implementação do sistema de captação de esgoto em conjunto com sua fiscalização e esclarecimento à população a respeito da conservação de áreas de recarga e as causas da contaminação da água subterrânea.

\section{AGRADECIMENTOS}

À Fundação de Amparo ao Desenvolvimento das Ações Científicas e Tecnológicas e à Pesquisa - FAPERO/CAPES pela bolsa concedida para realização desta pesquisa. À Fundação Universidade Federal de Rondônia - UNIR, em especial ao Programa de Pós-Graduação em Desenvolvimento Regional e Meio Ambiente - PGDRA pela oportunidade do desenvolvimento deste estudo. À Companhia de Águas e Esgotos do Estado de Rondônia - CAERD, Serviço Geológico do Brasil - 
CPRM, Secretaria Municipal de Planejamento e Gestão - SEMPLA e ao Sistema de Proteção da Amazônia - SIPAM pela disponibilização de dados e apoio técnico dos seus servidores. Ao geólogo MSc. Luiz Gilberto Dall’Igna pela colaboração no entendimento das técnicas de geoprocessamento.

\section{REFERÊNCIAS}

ADAMY, A. \& ROMANINI, S.J. Programa levantamentos geológicos básicos do Brasil. geologia da região Porto Velho-Abunã; Porto Velho (SC.20V-B-V), Mutum-Paraná (SC.20-V-C-VI), JaciParaná (SC.20-V-D-I), Abunã (SC.20-V-C-V), estados de Rondônia e Amazonas. Porto Velho, CPRM e DNPM, 273p., 1990.

ANA-AGÊNCIA NACIONAL DE ÁGUAS. Água na medida certa: a hidrometria no Brasil. Brasília/DF, ANA, 72p., 2012.

BETTENCOURT, J.S.; TOSDAL, R.M.; LEITE, J.R.W.B.; PAYOLLA, B.L. Mesoproterozoic rapakivi granites of the Rondônia Tin Province, southwestern border of the Amazonian Craton, Brazil-I. Reconnaissance U-Pb geochronology and regional implications. Precambrian Research, v. 95, p. 41-67, 1999.

BRASIL. Decreto-Lei $n^{\circ}$ 490, de 4 de março de 1969. Brasília, Diário Oficial da União,1969.

BRASIL. MINISTÉRIO DAS CIDADES. SNIS Sistema nacional de informações sobre saneamento: série histórica de indicadores e informações de água e esgoto do estado de Rondônia do ano 2014. Brasília, 1996. Disp. em: <http://app.cidades.gov.br/ serieHistorica>.

CAERD - COMPANHIA DE ESGOTO E SANEAMENTO DO ESTADO DE RONDÔNIA. Dados de teste de bombeamento dos poços tubulares da CAERD. Porto Velho, GEOPOÇOS, 2004.

CAMPOS, J.C.V. Avaliação preliminar do potencial hidrogeológico da cidade de Porto Velho (RO). In: CONGRESSO BRASILEIRO DE ÁGUAS SUBTERRÂNEAS, 10, 1998, São Paulo. Anais... São Paulo: ABAS, p. 43.

CAMPOS, J.C.V. \& MORAIS, P.R.C. Morfologia dos aquíferos da área urbana de Porto Velho. In: SIMPÓSIO BRASILEIRO DE RECURSOS HÍDRICOS, 13. 1999. Belo Horizonte Anais...Belo Horizonte: CD-ROM.

CPRM - SERVIÇO GEOLÓGICO DO BRASIL. SIAGAS -Sistema de informações de águas subterrâneas. Atualização permanente. Brasília/DF, CPRM, 1997. Disp. em: <http://siagasweb.cprm.gov.br/ layout/index.php>. Acessado em: 14 out. 2014.

CUSTODIO, E. \& LLAMAS, M.R. Hidrologia subterrânea. 1.ed. Barcelona, Omega S.A, 1157p., 1976.

DINIZ, J.A.O.; MONTEIRO, A.B.; FEITOSA, F.A.C.; FREITAS, M.A.; PEIXINHO, F.C. Metodologia para elaboração de mapas hidrogeológicos. In: CONGRESSO BRASILEIRO DE ÁGUAS SUBTERRÂNEAS, XVII, 2012, Bonito. Anais...Bonito: ABAS, p. 1-4.

ESRI, Software ArcGis 10.1, 2012.

EULER, A.; MILLIKAN, B.; BRITO, E.B.; CARDOZO, I.B.; LEROY, J.P.; CAMINHA, L.; HARGREAVES, M.I.; MOTTA, R.V.; CUNHA, S.; MATIAS, S.;
ALVES, V.; GLASS, V. O Fim da Floresta? A devastação das Unidades de Conservação e Terras Indígenas no Estado de Rondônia. RONDÔNIA, GTA Rondônia, 62p., 2008.

FEITOSA, F.A.C.; MANOEL FILHO, J.; FEITOSA, E.C.; DEMETRIO, J.G.A. Hidrogeologia: conceitos e aplicações. 3 ed., Rio de Janeiro, CPRM, 812p., 2008.

FETTER, C.W. Applied hydrogeology. 4 ed., New Jersey, Prentice Hall, 598p., 2001.

FORTES, L.T.G.; RAMOS, A.M.; SANTOS, L.A.R. (Orgs.). Normais climatológicas do Brasil 19611990. Brasília/DF, INMET, 465p., 2009.

GUERRA, A.T. Formação de lateritos sob a floresta equatorial amazônica (Território Federal do Guaporé). Revista Brasileira de Geografia. Rio de Janeiro, n.15, p.183-302, 1953.

IBGE-INSTITUTO BRASILEIRO DE GEOGRAFIA E ESTATÍSTICA. Resolução ${ }^{\circ} 1$ de 25 de fevereiro de 2005. Altera a caracterização do Sistema Geodésico Brasileiro. Rio de Janeiro, IBGE, 2005.

LEAL, J.W.L.; SILVA, G.H.; ABREU, A.S.; LIMA, M.I.C. Granito Serra da Providência. In: CONGRESSO BRASILEIRO DE GEOLOGIA, 1976. Ouro Preto Anais...Ouro Preto: SBG, v. 4, p. 59-74.

MORAIS, P.R.C. Mapa hidrogeológico do Estado de Rondônia. Texto explicativo, escala 1:1.000.000, Programa Recursos Hídricos, CPRM/ Porto Velho, 32p., 1998.

NASCIMENTO, T.C.N. A natureza dos materiais lateríticos entre Porto Velho e Morrinhos: relação morfológica e aplicação. Porto Velho, 2012. 79p. Dissertação (Mestrado em Geografia), Fundação Universidade Federal de Rondônia.

NASCIMENTO, T.C.N.; MANIESI, V.; ADAMY, A.; SANTOS, A.N. A Natureza e aplicação dos materiais lateríticos na área urbana e entorno de Porto Velho/RO. Revista Geonorte, Edição Especial, ISSN: 2237-1419, v. 2, n. 4, p. 11-19, 2012.

OLIVEIRA, C.E.S. Projeto materiais de construção civil da Folha de Porto Velho. Informe de recursos minerais. Porto Velho, CPRM, 558p., 2013.

PAYOLLA, B.L. As rochas graníticas e sieníticas das cachoeiras Teotônio e Santo Antônio, rio Madeira, Porto Velho, Rondônia: geologia, petrografia e geoquímica. Brasília, 1994, 145p. Dissertação (Mestrado em Geociências), Instituto de Geociências Universidade de Brasília.

QUADROS, M.L.ES. \& RIZZOTTO, G.J. (Orgs.). Geologia e recursos minerais do estado de Rondônia: texto explicativo do mapa geológico e de recursos minerais do estado de Rondônia, escala 1:1.000.000. Porto Velho, CPRM, 116p., 2007.

RIZZOTTO, G.J.; OLIVEIRA, J.G.F.; QUADROS, M.L.E.S.; CASTRO, J.M.R.; CORDEIRO, A.V.; ADAMY, A.; DANTAS, M.E.; MELO JUNIOR, H.R. Levantamento de informações para subsidiar o estudo de viabilidade do aproveitamento 
hidrelétrico (AHE) do rio Madeira. AHE Santo Antônio - Relatório Final. Porto Velho, CPRM, 2005. Disp. em: <http://rigeo.cprm.gov.br/xmlui/handle/ doc/15523>.

RONDÔNIA. Lei no 547, de 30 de dezembro de 1993. Porto Velho, Diário Oficial do Estado de Rondônia, 1993.

RONDÔNIA. Lei Complementar $n^{\circ}$ 255, de 25 de janeiro de 2002. Porto Velho, Diário Oficial do Estado de Rondônia, 2002.

SCANDOLARA, J.E. Geologia e recursos minerais do estado de Rondônia: texto explicativo e mapa geológico do estado de Rondônia. Brasília, CPRM, 97p., 1999.

SEMPLA - SECRETARIA MUNICIPAL DE PLANEJAMENTO E GESTÃO. Cartas planialti métricas (dxf) em escala 1:1.000 e imagem de satélite Worldview. Porto Velho, 2001.

SUGUIO, K. Geologia sedimentar. São Paulo/SP, Edgard Blucher Ltda, 400p., 2003.

USGS - UNITED STATES GEOLOGICAL SURVEY. The water cycle. United States, 1879. Disp. em: $<$ http://water.usgs.gov/edu/watercycle.html>. Acessado em: 09 abr. 2016 Aceito em 14 de março de 2018 